\title{
Can woody biomass support a pellet industry in southeastern Ontario: A case study
}

\author{
by S. Krigstin ${ }^{1}$, S. Wetzel| ${ }^{2 *}$, W. Mabee ${ }^{3}$ and S. Stadnyk ${ }^{2}$
}

\begin{abstract}
The European Renewable Energy Directive introduced in 2009 mandates a 20\% renewable energy share by 2020 and has driven a rising trend of wood pellet usage in EU member states that exceeds the domestic supply. This surge presents an exporting opportunity for pellet manufacturers in North America. In recent years Canada has supplied the bulk of its wood pellets to Europe; this is changing as western Canadian producers shift their focus to Asian markets. With this development and with a new dedicated pellet shipping port in Quebec, eastern Canada is well placed to increase the supply of pellets to Europe. The potential for a pellet industry in Bancroft, Ontario was evaluated by quantifying sawmill residues from twelve mills within a 200-km radius. Given recent downturns in the lumber industry, a pellet mill in Bancroft would deliver economic benefits to the local community. Using a sawmill residue model and forest biomass characterization database, these residues were evaluated to determine the potential output and quality of wood pellets. Standing trees in the region currently allocated as pulpwood were also analyzed as a potential source of biomass. The analysis of biomass resources in the Bancroft region illustrates the potential for a pellet industry meeting European pellet standards with a minimum annual production of 100000 tonnes.
\end{abstract}

Key words: sawmills, residue, wood biomass, bioenergy, pellets, southeastern Ontario, model, database, biomass

\section{RÉSUMÉ}

La Directive de l'Union européenne en matière dénergies renouvelables introduite en 2009 stipule que la part des énergies renouvelables devra atteindre 20 \% d'ici 2020 , qui a entraîné, chez les états membres de l'EU, un accroissement de l'utilisation de granules de bois dépassant la capacité de production locale. Cet accroissement de la demande constitue une occasion intéressante pour les producteurs de granules de l'Amérique du Nord. Au cours des dernières années, le Canada a exporté la majeure partie de ses granules de bois en Europe; cette situation est en voie de changer puisque les producteurs de l'Ouest canadien accordent de plus en plus d'attention aux marchés asiatiques. Avec tous ces changements et la construction d'un quai de transbordement dédié à lexpédition de granules dans le port de Québec, l'Est du Canada est en bonne position pour accroître ses expéditions de granules vers l'Europe. On a évalué la possibilité de développer un centre de production de granules à Bancroft en Ontario à partir des volumes de résidus de sciage provenant de 12 scieries situées dans un rayon de $200 \mathrm{~km}$. Compte tenu du ralentissement qu'a connu l'industrie de sciage, la création d'un centre de production de granules à Bancroft apporterait des retombées économiques intéressantes pour la communauté environnante. Les résidus des scieries ont été évalués au moyen d'un modèle de production de résidus de sciage et d'une base de données sur les caractéristiques de la biomasse forestière afin de déterminer la quantité potentielle et la qualité des granules produites. On a aussi évalué le potentiel des arbres de la région destinés à la production de bois à pâte comme source potentielle de biomasse. Lanalyse des sources de biomasse de la région de Bancroft démontre qu'il serait envisageable de produire annuellement 100000 tonnes et plus de granules répondants aux exigences européennes.

Mots clés : scieries, résidus, biomasse ligneuse, bioénergie, granules, sud-est de l'Ontario, modèle, base de données, biomasse

\footnotetext{
${ }^{1}$ Faculty of Forestry, University of Toronto, Toronto, ON M5S 3B3

${ }^{2}$ Natural Resources Canada, Canadian Forest Service, Canadian Wood Fibre Centre, Ottawa, ON K1A 0E4 Corresponding author: suzanne.wetzel@canada.ca.

${ }^{3}$ Associate Professor, Department of Geography and Planning, Queen’s University, Kingston, ON K7L 3N6
} 


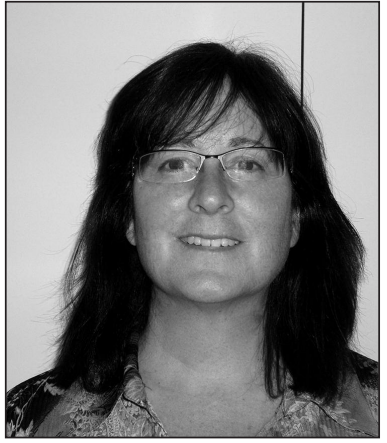

S. Krigstin

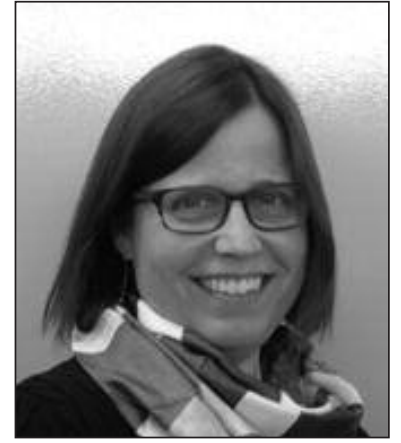

S. Wetzel

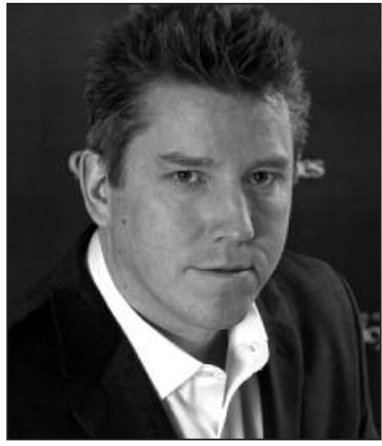

W. Mabee

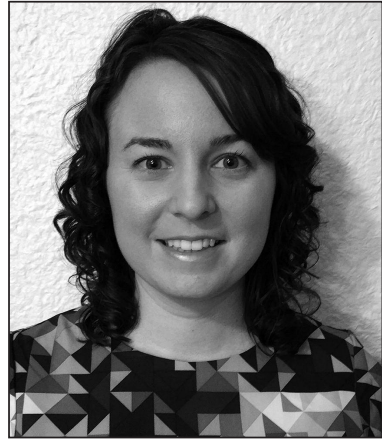

S. Stadnyk

\section{Introduction}

North American wood pellet production has significantly increased since the 2000s, driven largely by demand in Europe which in turn is rooted in policy decisions (Arsenault 2015). Western Canada has long dominated Canadian pellet exports, but since 2013 producers in this region have begun to shift their exports to Asia (WRI 2013). Increasing overseas demand and access to Atlantic ports with access to Europe present an opportunity for eastern Canada to develop a bioenergy industry. Diversifying forest products will help to stabilize the local economy in a region that relies heavily on its forestry sector and has experienced decline in recent years (OMNR 2012).

The primary policy driver for Canadian wood pellet use in Europe is the Renewable Energy Directive, implemented by the European Commission (EC) in 2009, which sets a binding target for member states of $20 \%$ renewable energy in final energy consumption by 2020 (European Commission 2009). The Directive has been instrumental in increasing demand for wood pellets as an alternative to fossil fuel sources across the European Union (EU). In Europe, wood pellets are used in diverse applications including residential boilers and stoves, medium-sized district energy plants and large combined heat and power (CHP) plants (Flach et al. 2014). The Joint Wood Energy Enquiry suggests that about $4.3 \%$ of total energy consumption in 2011 was derived from wood, and that wood-based energy accounted for $42 \%$ of all renewable energy consumed in that year (JWEE 2015). Other sources suggest that wood energy consumption is higher; Eurostat reported that primary energy production from solid biofuels (including pellets) was 3476 petajoules (PJ) in 2012, which is about $10.5 \%$ of primary energy production in the 27 nations of the EU (Aguilar et al. 2014).

The USDA GAIN Report on EU reports on the current status of wood pellet use in Europe. Currently Europe is the biggest producer of wood pellets in the world, with production capacity increasing from 8.6 million tonnes (Mt) in 2007 to about 16.4 Mt in 2013, a near doubling in capacity; actual production has risen from $5.8 \mathrm{Mt}$ in 2007 to about 11.5 Mt in 2013 (Flach et al. 2014). Over the same period however, EU consumption of wood pellets has increased from $6.5 \mathrm{Mt}$ in 2007 to $17.5 \mathrm{Mt}$ of pellets in 2013, with demand expected to reach $21 \mathrm{Mt}$ in 2015 and as high as $50-80 \mathrm{Mt}$ by 2020 (Flach et al. 2014). This means much greater reliance on imports, primarily from the United States, Canada, and Russia. In 2013, wood pellet imports to the EU were dominated by shipments from the United States (2.8 Mt) and Canada (1.9 Mt),

corresponding to $16 \%$ and $11 \%$ of EU consumption and $46 \%$ and $32 \%$ of EU imports in the year (Flach et al. 2014).

The United States produced about 4.1 Mt per year of wood pellets as of the end of 2012, and production continues to rise with domestic consumption of wood energy predicted to increase 47\% between 2014 and 2030 (Aguilar et al. 2014). Significant wood pellet production capacity has been developed in recent years in the US southeast, where capacity tripled from 2012 to 2013 (WRI 2013). In 2014, US wood pellet production capacity was reported at about $10 \mathrm{Mt}$ per year, with another 2.7 Mt under construction (Aguilar et al. 2014). While this growth is influenced by increases in the EU demand for pellets (NREL 2013), it is speculated that the recent strengthening of the US currency in relation to the UK pound and the euro will challenge profit margins and affect European purchases of US pellets (Strauss 2015).

Canada produced about $1.8 \mathrm{Mt}$ per year of wood pellets as of the end of 2014 (Arsenault 2015); as in the US, wood pellet production has been rising steadily for several years. The wood pellet industry brings significant value to the domestic forest sector, and the foreign demand is driving the development of the sector: more than $90 \%$ (1.64 Mt) of Canadian production was exported in 2014 with a value of US $\$ 214.5$ million (NRCan 2013, Statistics Canada 2015). In 2014, 60\% of Canadian wood pellet exports were shipped to the United Kingdom, while the US received 13\% of Canadian exports (Statistics Canada 2015). Canada currently has 55 operating pellet mills with a combined production capacity of 5.6 Mt/year (Wood Pellet Association of Canada 2015). The largest production volumes are split amongst three provinces: twelve mills in British Columbia produce 55\%, nine Quebec mills produce $18 \%$, and five Ontario mills contribute $12 \%$ to pellet production (Canadian Biomass 2015). It is important to note that shipments from Canada to Asia have increased from $8 \%$ of the total wood pellet exports in 2012 to $13 \%$ in 2014 (Statistics Canada 2015), with the bulk of the increase coming from British Columbia mills. A gradual shift in exports to Asian markets from western Canada could benefit the pellet industry in eastern Canada and parts of the US southeast, which are expected to continue supplying the European market (WRI 2014). Infrastructure for exporting pellets to Europe from southeastern Canada is set to improve with the construction of the first dedicated pellet export facility along the St. Lawrence Seaway at the Port of Quebec (Pulp and Paper Canada 2014).

As of early 2015, Ontario has five operating pellet mills and four under construction, with combined production 
capacity of over $1 \mathrm{Mt} / \mathrm{year}$; these mills are located in the northern and southwestern portions of the province (Canadian Biomass 2015). At the current time, there are no industrial pellet manufacturing facilities operating in southeastern Ontario, although this region has extensive forest lands and historically has depended upon forest operations for employment and economic opportunity. The scale of forestry operations in southeastern Ontario is much smaller than in northern parts of the province with small family-owned and operated sawmills dominating the regional industry. Most of the wood that is harvested goes directly to small sawmills, which in turn have historically supplied wood residues (chips) to local pulp and composite board plants (OMNR 2004). Unfortunately, local board and pulp plants have for the most part closed, leaving few buyers for sawmill residues and challenging the economics of all forest operations (Opeongo Forestry Service 2009). The number of forestry-related jobs in Ontario is steadily declining and in 2006 and 2007 thousands of jobs were lost due to permanent and indefinite mill closures (OMNR 2012).

Developing a wood pellet industry in southeastern Ontario would serve to diversify the forest sector and make it more resilient to economic fluctuations. Current trends in wood pellet use suggest that pellets from eastern Canada will be in demand in Europe and possibly the USA; in addition, using forest biomass to generate electricity is a promising opportunity (OMNR 2012). Taken together, these factors form a strong rationale for developing such an industry. This paper explores the potential for wood pellet production from the Great Lakes-St. Lawrence forest region in southeastern Ontario, a forest that is characterized by a unique mixed tree species population (Rowe 1972). The study builds on previous work (see Levin et al. 2011) to quantify wood residues from sawlogs allocated to mills in Bancroft and the surrounding area. Sawlogs are suitable in size and quality for the production of lumber. The sawlog wood residue data is used to determine the scale of pellet mill that could be supported by the operations. Potentially available biomass currently designated as pulpwood is also assessed. Pulpwood is lower-quality wood traditionally used to produce paper and demand for this wood stream is declining. An examination of the residue characteristics and energy value is carried out to assess the region's ability to produce pellets that meet ENplus certification standards. ENplus certification is the recognized standard in Europe and complies with European standards for solid biomass. The operating costs of a pellet mill are discussed including consideration for additional processing equipment that may be required depending on the type of available residues.

\section{Methods}

\section{Sawmill selection}

Sawmills within a 200-km radius centered on Bancroft, Ontario were included in this study. Twelve sawmills are located within the area (Fig. 1). The relatively small size of this circle was selected to minimize transportation costs to a proposed pellet mill located in or near the town. The selected sawmills receive wood from a total of six forest management units (FMUs) in southeastern Ontario: Bancroft-Minden Forest, Nipissing Forest, Ottawa Valley Forest, Algonquin Park Forest, Mazinaw-Lanark Forest, and French-Severn For- est. The six FMUs were determined by reviewing the forest management plans (FMPs) issued by each management unit; the FMPs are available on the Ontario Forest Management Plan website ${ }^{4}$.

\section{Wood volume supply}

The size of wood allocation given to various sawmills are stated in the FMPs issued by the FMUs under consideration. Data collected from the FMPs required for the residue analysis were sawmill name, wood output products (i.e., the breakdown between sawlogs and pulpwood), planned volume over a 5-year period, and species harvested.

To determine each sawmill's yearly cubic residue production, annualized harvest volumes, species, and output products were compiled into a spreadsheet. The sawlog volumes were used to determine available sawmill residue supply and the pulpwood volumes were considered potential fibre sources that could become available due to changes in the local economy.

\section{Sawmill residue quantification}

Sawmill residues and products for each mill and species were determined by processing the sawlog volumes through a sawmill residue calculation model developed previously (see Krigstin et al. 2012). The inputs for the model were log volume, tree species, proportion of small end diameter, and type of mill (dimension, stud, board, hardwood). To complete the residue calculations the model has a built-in database of tree characteristics for over 400 species including wood densities and bark proportion. The model outputs quantity of lumber, bark, chips, and sawdust in cubic metres and green tonnes. Green tonnes refer to freshly felled wood with a moisture content of typically 50\% (Cutshall et al. 2012).

\section{Pulpwood quantification}

Wood allocated as pulpwood was considered potentially available fibre. The wood volumes were processed through the sawmill residue calculation model (Krigstin et al. 2012) and the lumber, residue, and shrinkage volumes were combined. The model was used for this conversion to ensure the same species specific density and moisture values were applied to the fibre as in the sawmill residue determination.

\section{Residue characteristics}

Wood residue characteristics were gathered from a forest residue database containing testing results on the physical characterization of mill residue streams in 2012 (S. Krigstin, personal communication, February 25, 2015). Analysis was carried out in the Forest Biomaterial Characterization Lab at the Faculty of Forestry, University of Toronto. The quality parameters of interest for this analysis were moisture content, ash content, gross calorific value, and chlorine. Moisture content and gross calorific value are measures of net energy content; ash content and chlorine concentrations are indicators of boiler efficiency since high levels can lead to boiler fouling (Clarke and Preto 2011).

Moisture content was determined using the oven dry method by placing the samples in a $105^{\circ} \mathrm{C}$ oven for 24 hours. The procedure was based on ASTM E871-82 and moisture

\footnotetext{
${ }^{4}$ http://www.efmp.lrc.gov.on.ca/eFMP/home.do
} 


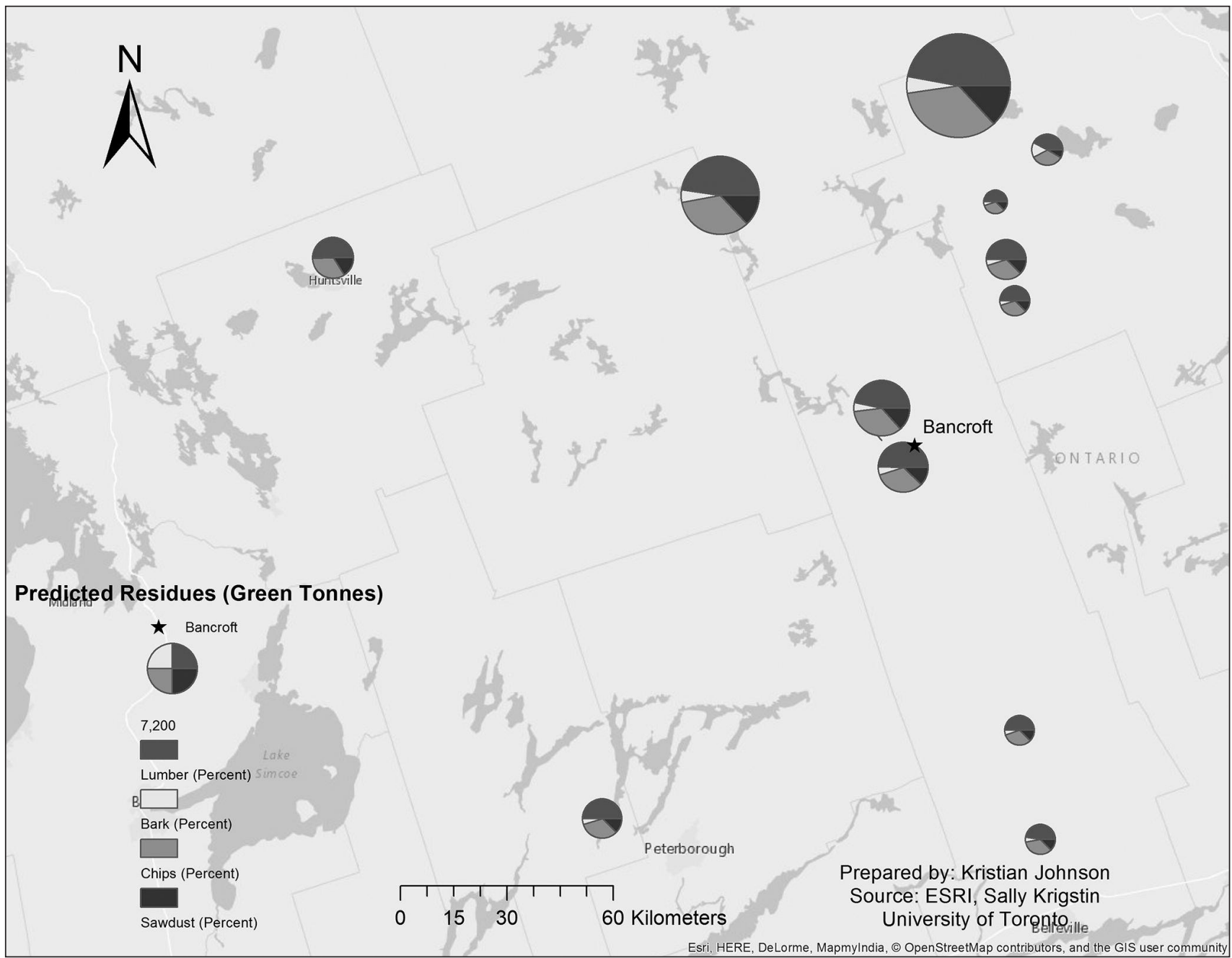

Fig. 1. Sawmill location map with residue volumes

content was calculated on a wet and dry basis. Ash content of the sawmill residue samples was determined at $550{ }^{\circ} \mathrm{C}$ following the method ASTM D1102 using a muffle furnace. The gross calorific value (higher heating value, $\mathrm{HHV}$ ) of the samples was determined using a Parr 1108 adiabatic oxygen combustion bomb calorimeter as specified in ASTM D2015-77.

Net calorific value (lower heating value, LHV) was calculated from the gross calorific value according to equation 1.

$$
\text { (1) } L H V=[H H V s a m p l e-\lambda(\operatorname{MCod}+9 H)](1-M C w e t)
$$

Where LHV is the lower heating value in $\mathrm{MJ} / \mathrm{kg}$, HHV is the higher heating content of dry fuel, $\lambda$ is the latent heat of vaporization of water $\left(2.31 \mathrm{MJ} / \mathrm{kg}\right.$ at $\left.25{ }^{\circ} \mathrm{C}\right), \mathrm{MC}_{\text {wet }}$ is the moisture content of fuel on a wet basis, $\mathrm{MC}_{\mathrm{od}}$ is the moisture content of fuel on a dry basis, $\mathrm{H}$ is the mass fraction of hydrogen in dry fuel. $\mathrm{MC}_{\text {wed }}, \mathrm{MC}_{\mathrm{od}}$, and $\mathrm{H}$ are expressed as a fraction and assumed to be $0.09,0.0989$, and 0.0591 respectively.

The bark characteristics were collected from the Energy Research Centre for the Netherland's Phyllis database which contains information on the composition of biomass and waste. $^{5}$

\section{Pellet composition}

The pellet composition for ash, LHV, and chlorine was determined using moisture contents and quality parameters from the databases. The calculated wood residue dry weights for each species were applied to the quality parameters to determine the contribution from each species. The same process was done for the bark proportion. The bark and wood values were combined for each species, maintaining the residue ratios. Composition of the final pellet was determined by combining all species proportions to get the final ash, LHV, and chlorine values.

\section{Results and discussion}

\section{Sawmill residues}

The twelve sawmills in the study produced 230340 green tonnes of residue in the form of shavings, chips, sawdust, and bark. Residue breakdown by species (Fig. 2.) indicates that sugar maple and white pine are the two most common species in the study area. Analysis of annual residues for each sawmill (Fig. 3.) suggests that four of the mills provide the bulk of the residues, with the largest generating just over 65000 green tonnes of residue per year.

\footnotetext{
${ }^{5}$ https://www.ecn.nl/phyllis2/
} 


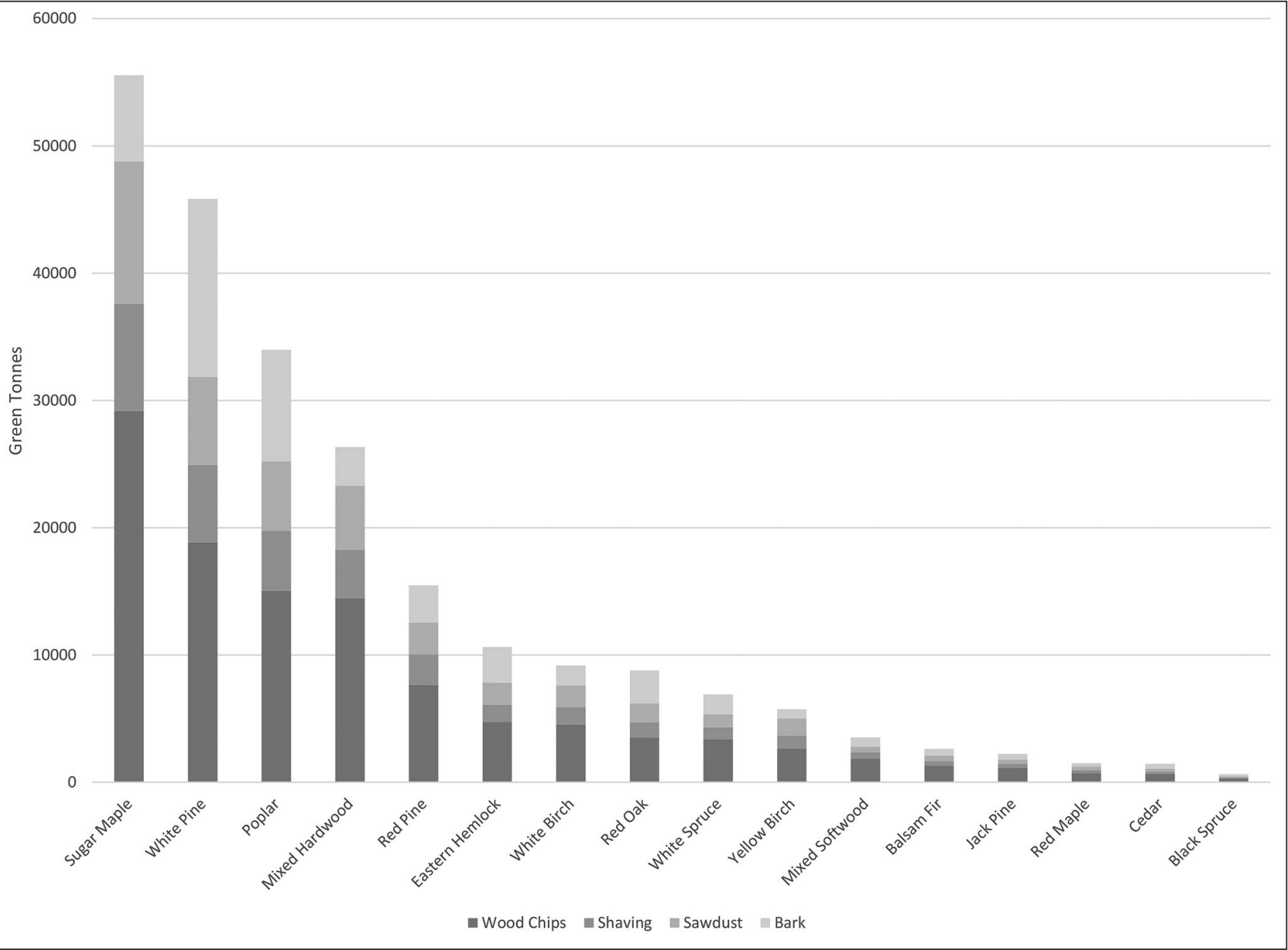

Fig. 2. Annual sawmill residues for each tree species from the 12 sawmills

\section{Pulpwood volume}

Wood allocated as pulpwood represents $173612 \mathrm{~m}^{3}$ per year in the case study area. Processing the wood through the model has identified 168389 green tonnes of potential biomass (Fig. 4). This wood is currently allocated but has been quantified to illustrate the biomass potential in the area.

\section{Pellet quality}

ENplus certification is a recognized pellet standard in Europe (EPC 2013). Certification complies with the European standards for solid biomass introduced in 2011. The certification system aims to ensure wood pellets for heating and CHP up to $1 \mathrm{MW}$ output power in residential, commercial and public buildings are of constant quality (EPC 2013). There are currently twelve countries with national pellet associations that license ENplus pellets ${ }^{6}$. The Wood Pellet Association of Canada is the National Licensor for the ENplus ${ }^{\mathrm{TM}}$ wood pellet certification system in Canada. The ENplus certification covers three pellet quality classes with different demands on the raw material and wood pellet characteristics. The specifications (Table 1) are in line with the International Standard Organization (ISO) solid biofuel specifications ISO 17225.

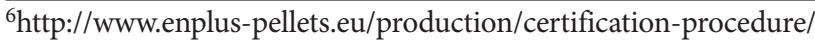

\section{Sawmill residue pellet quality}

The properties of wood pellets made from the sawmill residue were calculated to determine if they would meet the ENplus quality standards. By applying the moisture contents from the database there would be 152262 dry tonnes of residue. In this case study, the pellets made out of a wood/bark blend met the requirements for A2 pellets for industrial use (Table 2). The cost of sawmill residues ranges from US \$7.8-46.8/dry tonne, therefore the annual cost to purchase the available residue would range from US \$1.2- \$7.1 million (Roser 2013).

\section{Pulpwood pellet quality}

The properties of wood pellets made from pulpwood were calculated to determine if they would pass the quality standards. By applying the moisture contents from the database there would be 112515 dry tonnes of residue. In this case study, the pellets made out of a wood/bark blend met the requirements for $\mathrm{A} 2$ pellets for commercial and residential use (Table 2).

\section{Properties of pellets made with bark}

It is important to consider the impact the addition of bark would have on pellet quality since traditional pellets do not use bark. Bark generally has higher ash content and high amounts of nitrogen and sulphur which can lead to problems 


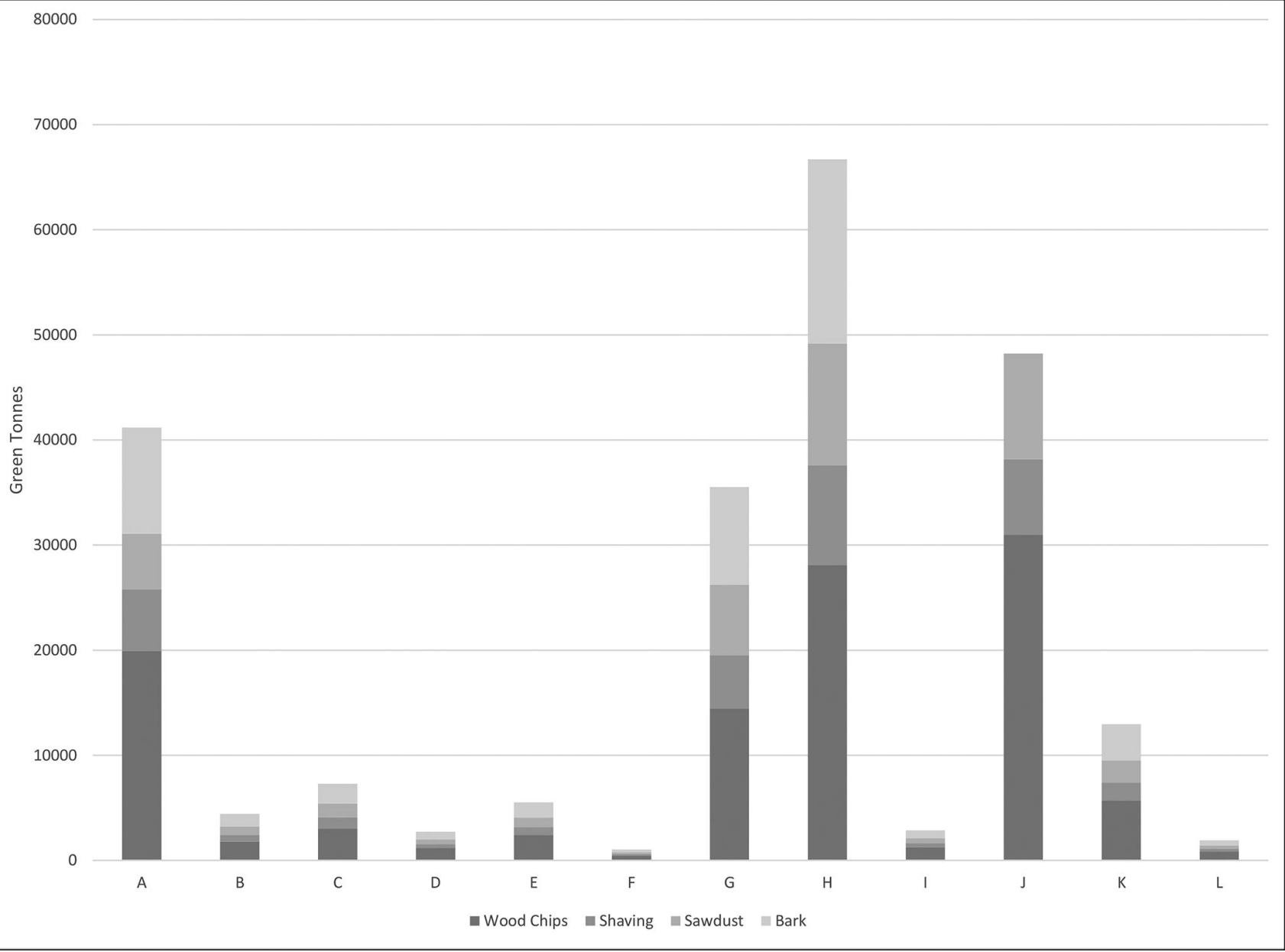

Fig. 3. Annual wood residues for each sawmill

with nitrogen oxides and sulphur dioxide emissions during combustion. Bark also has a higher lignin content which contributes to a higher calorific value. A study analyzing the effect of different bark concentrations of Scots pine pellets (Filbakk et al. 2011) found that bark composition up to $30 \%$ would not have an effect on the quality characteristics of the pellets. In this southeastern Ontario case study, bark accounts for $20.5 \%$ of sawmill residues and $14.5 \%$ of pulpwood. Pellets made purely out of bark would have a higher ash content which would place them in a lower quality class. Blending the bark with wood residue produces a higher quality pellet compared to pellets made only with bark and utilizes the full potential of biomass in the region (Table 2).

\section{Optimal pellet mill size}

A 2009 report investigating renewable energy opportunities in southeastern Ontario forests prepared by the Opeongo Forestry Service concluded that pellet mills with an annual production rate of 60000 to 100000 tonnes with nearby supplies of residues were considered optimal. The report stated that a 60000 tonne plant could be operated with a manageable group of five people per shift, and could be expanded to a maximum annual production of 100000 tonnes. In this configuration, it is not possible to increase capital efficiency of the pellet plant by expanding beyond 100000 tonnes, as fur- ther expansion would require additional dryers and refining equipment which would increase capital costs.

Research has shown that with a higher plant capacity the operating costs decrease considerably more than the capital cost of the plant due to the increase in annual pellet production rate. Mani et al. (2006) concluded that at an annual production rate of 45000 tonnes ( $6 \mathrm{t} / \mathrm{hour}$ ), the pellet production cost was US $\$ 51$ per tonne, while at an annual production rate of more than 75000 tonnes (10 t/hour) the cost decreased to roughly US $\$ 40$ per tonne. Assuming a pellet plant in the Bancroft region had an annual production of 100000 tonnes, and operated 24 hours a day six days a week, the hourly production rate would be 13.35 tonnes (Table 3), which is well above the recommended 10 tonnes/hour required to decrease production costs.

This study has identified 183140 green tonnes of sawmill residue in the form of chips, sawdust, and shavings. This number increases to 230340 green tonnes when bark is included. A wood pellet mill with an annual capacity of 100000 tonnes is estimated to require 150750 tonnes of green sawdust with $40 \%$ moisture content (Hoque et al. 2006). This indicates that, including bark, there is 1.5 times as much feedstock required for a 100000 tonne/year pellet plant in the Bancroft area. 


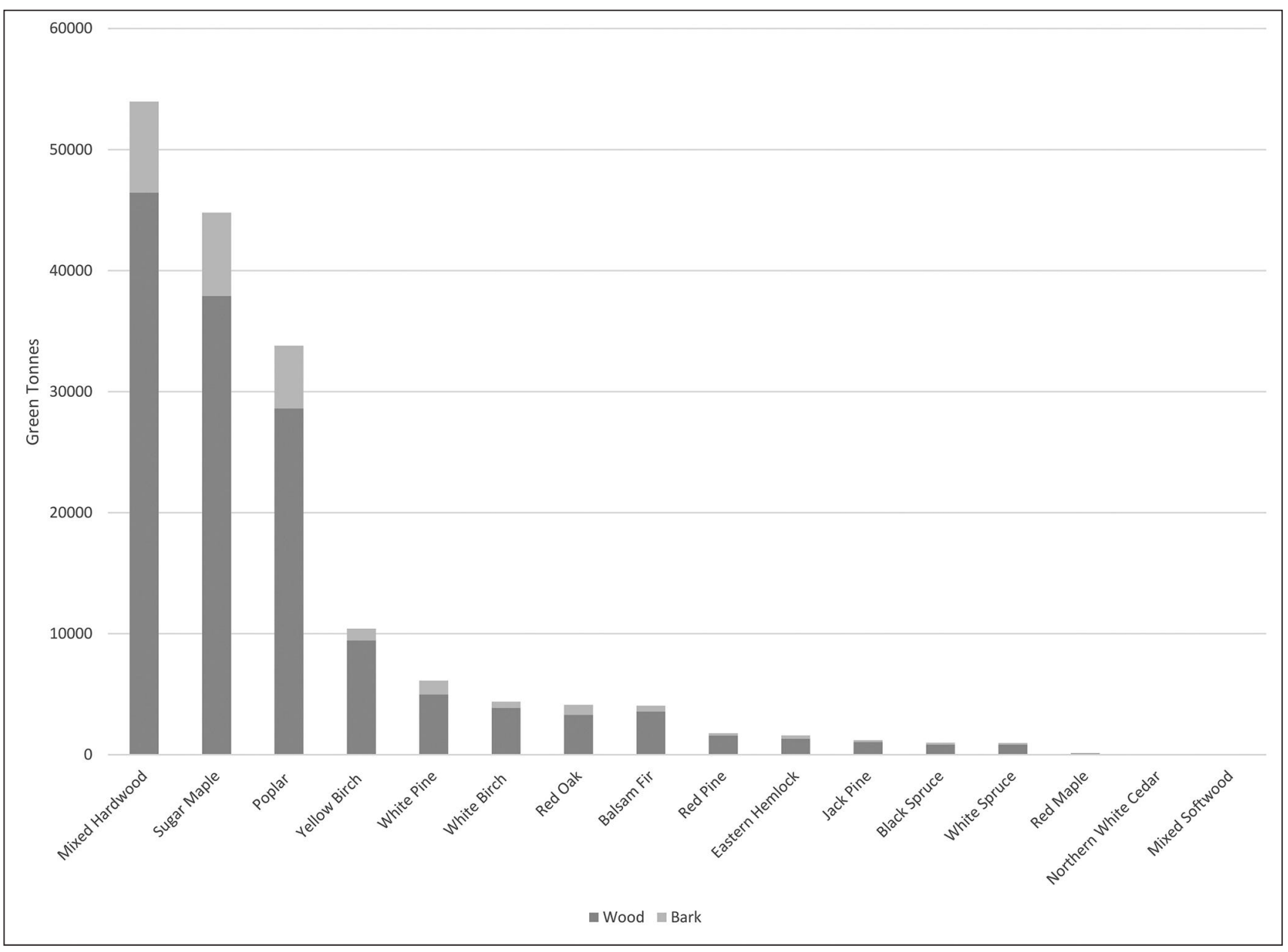

Fig. 4. Annual pulpwood allocation for each tree species

Table 1. ENplus pellet quality classes

\begin{tabular}{|c|c|c|c|}
\hline Pellet Type & A1 & A2 & B \\
\hline Material & $\begin{array}{l}\text { Stemwood, chemically } \\
\text { untreated residues }\end{array}$ & $\begin{array}{l}\text { Whole trees without roots, } \\
\text { stemwood, logging residues, } \\
\text { chemically untreated residues }\end{array}$ & $\begin{array}{l}\text { By-products and } \\
\text { residues from wood } \\
\text { processing industry }\end{array}$ \\
\hline Typical Applications & $\begin{array}{l}\text { Private household } \\
\text { boilers or stoves }\end{array}$ & $\begin{array}{l}\text { Use in larger } \\
\text { installations }\end{array}$ & $\begin{array}{l}\text { Larger industrial } \\
\text { heating plants }\end{array}$ \\
\hline MC (wt.\% wet) & - & $<10$ & - \\
\hline Ash Content (wt.\% dry) & $\begin{array}{c}\text { CR: } \leq 0.7 \\
\text { IU: } \leq 1\end{array}$ & $\begin{array}{l}\text { CR: } \leq 1.5 \\
\text { IU: } \leq 1.5\end{array}$ & $\begin{array}{l}\mathrm{CR}: \leq 3 \\
\mathrm{IU}: \leq 5\end{array}$ \\
\hline Net Calorific Value (MJ/kg) & $\begin{array}{l}\mathrm{CR}: \geq 16.5 \\
\mathrm{IU}: \geq 16.5\end{array}$ & $\begin{array}{c}\text { CR: } \geq 16.3 \\
\text { IU: } \geq 16\end{array}$ & $\begin{array}{l}\text { CR: } \geq 16 \\
\text { IU: } \geq 15.5\end{array}$ \\
\hline Bulk Density (kg/m3) & - & $\geq 600$ & - \\
\hline Chlorine (wt.\% dry) & $\begin{array}{l}\text { CR: } \leq 0.02 \\
\text { IU: } \leq 0.05\end{array}$ & $\begin{array}{l}\text { CR: } \leq 0.02 \\
\text { IU: } \leq 0.05\end{array}$ & $\begin{array}{l}\text { CR: } \leq 0.03 \\
\text { IU: } \leq 0.05\end{array}$ \\
\hline
\end{tabular}

CR: Commercial and residential

IU: Industrial use 
Table 2. Properties of wood pellets made from sawmill residue and pulpwood

\begin{tabular}{|c|c|c|c|c|c|c|c|}
\hline & & \multicolumn{3}{|c|}{ Sawmill Residue } & \multicolumn{3}{|c|}{ Pulpwood } \\
\hline & & wood & bark & wood and bark & wood & bark & wood and bark \\
\hline Mass & green tonnes & 183142 & 47198 & 230340 & 146539 & 24924 & 171463 \\
\hline Mass & dry tonnes & 117129 & 35134 & 152262 & 96093 & 18403 & 114496 \\
\hline Ash & $\%$ & 0.712 & 3.187 & 1.284 & 0.713 & 3.728 & 1.197 \\
\hline Net Calorific Value & $\mathrm{MJ} / \mathrm{kg}$ & 17.181 & 18.640 & 17.621 & 16.964 & 18.087 & 17.144 \\
\hline Chlorine & $\%$ & 0.021 & 0.026 & 0.022 & 0.013 & 0.036 & 0.017 \\
\hline
\end{tabular}

Table 3. Hourly pellet production rate calculation

\begin{tabular}{lll}
\hline Daily operation & hour/day & 24 \\
Weekly operation & day/week & 6 \\
Annual operation & hours/year & 7488 \\
Annual pellet production & tonne/year & 100000 \\
Hourly pellet production & tonne/hour & 13.35 \\
\hline
\end{tabular}

\section{Residue pre-treatment Milling wood chips}

Wood chips account for $60 \%$ of sawmill wood residues in this study and incorporating that material into wood pellets is one means to optimize residue use. Extra costs are associated with processing wood chips since the chips must be processed through a hammer mill equipped with a screen size of 3.2 to $6.4 \mathrm{~mm}$ to reduce them to a size suitable for pelleting. In addition to extra equipment and fuel costs, hammer mills can have high repair and maintenance costs due to wear and tear on the equipment that can add up to $10 \%$ of the purchase cost compared to $2 \%$ for other equipment in the pellet production plant (Mani et al. 2006). Two studies published by Hoque et al. (2006) and Mani et al. (2006) focused on the economics of producing pellets in North America. Each study analyzed total capital and operating costs of a pellet mill with a defined production rate. The studies show that the additional cost of a hammer mill can range between $0.96 \%-1.88 \%$ of total capital and operating costs of the pellet mill.

\section{Biomass drying}

Operating a dryer in the pellet plant is a necessary but costly component as green woodchips are about $50-65 \%$ moisture content. While moisture acts as a binding agent in the pellet productions process, too much moisture makes the process difficult. Optimal moisture contents vary based on the pelletizing temperature, but they typically ranges from $8-15 \%$ (Hoque et al. 2006). Mani et al. (2006) determined the cost for a drying operation to be $20 \%$ of the total capital and operating cost distribution for a pellet plant. Mani et al. (2006) investigated the effect of different burner fuel options on the pellet production cost and found the lowest cost option to be wet biomass compared to dry biomass, fuel pellets, and coal.

A reduction in greenhouse gas emissions is another benefit of using biomass for drying. A life cycle assessment carried out on Swedish wood pellet production found that total emis- sions for pellet production were significantly lower if heat for drying was produced with biomass instead of oil (Hagberg et al. 2009).

\section{Supply chain considerations \\ Truck volume and distance}

Transportation logistics can have a significant impact on the cost of transporting raw materials to the pellet mill. Aman et al. (2011) found that a truck with a payload of 33 green tonnes of chips saves $31 \%$ of the total delivered cost for the raw material compared to the same truck with a payload of 16 green tonnes. Haul costs are approximately US $\$ 0.18$ /tonne/ $\mathrm{km}$ (Aman et al. 2011). Therefore it is beneficial to locate the pellet mill close to the residue supply since transportation distance will impact the trucking costs.

\section{Moisture content}

Delivering a lower moisture content raw material to the pellet plant is ideal for saving transportation costs and reducing emissions. A life cycle analysis of a Swedish pellet mill determined that approximately $30 \%$ of the total emissions come from the transport of raw materials and fuels to the plant and pellets to the consumer (Hagberg et al. 2009). Part of the study considered transportation of different materials and the emissions per MJ of pellets. Transportation of wet sawdust had calculated emissions ranging from 0.18-0.93 $\mathrm{g} \mathrm{CO}_{2 \mathrm{eq}} / \mathrm{MJ}$ pellets, and dry material a range of $0.03-0.86 \mathrm{~g} \mathrm{CO}_{2 \mathrm{eq}}^{2 \mathrm{eq}} / \mathrm{MJ}$ (Hagberg et al. 2009). Truck load limits are based on the weight of material and since drier materials have a higher energy content it would be optimal to ship drier materials. Freshly felled trees have a moisture content of approximately $50 \%$ wet basis, however if left to dry for at least four weeks before processing the moisture content can be reduce to $30-35 \%$ through air-drying. The extra drying decreased delivered costs on an energy basis by over $50 \%$ for materials with a moisture content decrease from $55 \%$ to $30 \%$ (Cutshall et al. 2012). While air-drying may not be practical for some residues, it does highlight the importance of reducing moisture content. Hoque et al. (2006) noted that cost per tonne of transporting chips with $45 \%$ and $<10 \%$ moisture content cost US $\$ 0.31 /$ tonne $/ \mathrm{km}$ and US $\$ 0.28 /$ tonne $/ \mathrm{km}$ respectively.

\section{Pulpwood harvesting}

Pulpwood has been allocated by the forest management companies to mills as dictated in the FMPs. This case study is exclusively in the Great Lakes-St. Lawrence forest region which is characterized by its unique mixed tree species popu- 
lations (Rowe 1972). Partial harvesting systems such as shelterwood and selection system are commonly employed in this region. Both systems bring pulpwood and saw logs to the landing concurrently where they are sorted into their respective product categories. Selection harvesting is used for shade tolerant trees and mimics individual trees dying by insect or disease and wind storms while maintaining the uneven aged composition. Shelterwood harvesting is mainly used in areas containing pines and hardwoods that tolerate partial shade and emulates small periodic ground fires resulting in trees that are mostly the same age (OMNR 2015). The lower quality pulpwood must be removed from harvested areas in order to successfully regenerate the forest and provide access to higher quality wood which sawmills depend upon.

In areas where the pulp and paper industry is no longer vying for the forest resource, forest managers often have a difficult time allocating the harvested pulp and chip wood material to an end-user. If a pellet mill existed within such an area, mill and forest managers might secure a contract for this surplus material. All forest material harvested on Crown land is subject to stumpage and forest renewal fees. For example, poplar has a stumpage fee of US $\$ 0.46 / \mathrm{m}^{3}$ and a forest renewal fee of US $\$ 0.38 / \mathrm{m}^{3}$ (OMNR 2015). The raw material price for pulpwood compared to sawmill residue would be affected by these fees in addition to the cost of transportation from the harvesting site to the mill.

\section{Additional considerations}

\section{Residue competition and other sources of biomass}

This study has determined that there is enough sawmill residue to support one 100000 tonne/year pellet mill; however, if more than one pellet mill was to be constructed in the area there will be competition for resources that could drive up the price of sawmill residues.

Currently there are not any operating pellet mills within $400 \mathrm{~km}$ of Bancroft (Canadian Biomass 2015). Other possible competition for sawmill residue include mulch, animal bedding, pulp and paper, and panel board (Levin et al. 2011). A possible source of fibre competition in southeastern Ontario is Pembroke MDF, a medium-density fibreboard mill in Pembroke which reopened in 2014. Prior to its closure in 2008, the mill used over 300000 tonnes/year of chips, sawdust, and bark from sawmill sources and remote whole log chipping operations (Opeongo Forestry Services 2009). A biomass electricity generating station would also be a source of competition for mill residues. Ontario Power Generation (OPG) currently has two biomass generating stations in Northern Ontario: Atikokan GS and Thunder Bay GS (OPG 2014). OPG's coal-fired Nanticoke Generating Station, $370 \mathrm{~km}$ southwest of Bancroft, ceased operation in 2013 and it was recently confirmed that the generating station would not be converted to biomass (Sonnenberg 2015); therefore, it will not compete for sawmill residues in southeastern Ontario.

It should be noted that we have considered only sawmill residues and allocated pulpwood in this study, as this allowed us to utilize previously developed databases of residue quantification and characterization. Several groups such as the Eastern Ontario Model Forest, Ontario's Ministry of Agriculture, Food and Rural Affairs, and the University of Guelph continue to study various sources of biomass suitable for bioe- conomy development within this region, including biomass grown on marginal and abandoned agricultural lands. In addition, local initiatives continue to consider and move ahead with projects such as a local CHP plant.

\section{Economic uncertainties}

The value of the Canadian dollar has dropped in the past year. In July 2014 the CAD-USD exchange rate was US \$0.94; in July 2015 it was US $\$ 0.78$ (Bank of Canada 2015a). As stated by Strauss (2015), the US dollar strengthening against many of the world's currencies means that the cost per tonne of US wood pellets in Euros is increasing. The drop in Canadian currency compared to the US currency may improve the competitiveness of Canadian pellets in the European market relative to US pellets. In the winter 2014-15 Business Outlook Survey from the Bank of Canada, some businesses indicated that the recent depreciation of the dollar should help them to regain market share and boost competitiveness. Additionally, indicators of future sales growth have improved more for firms with international customers than for those selling mainly to domestic markets (Bank of Canada 2015a).

A major driver of economic uncertainty is the price of oil which has fallen $50 \%$ in the past two years from a monthly average in January 2014 of US \$ 82.17/barrel WTI to a monthly average in December 2015 of US\$ 48.67/barrel $\mathrm{WTI}^{7}$. According to the winter 2014-15 Business Outlook Survey, firms in Eastern and Central Canada are planning to increase their investment spending due to the drop in oil prices (Bank of Canada 2015a). In the spring 2015 Business Outlook Survey, many businesses maintained that lower oil prices, which are driving a weaker Canadian currency as noted above, actually support their business outlook, and that the combined impact of these factors is raising foreign demand for their products (Bank of Canada 2015b). It is important to note that wood pellets, while an energy product, compete primarily with coal (and to a lesser extent natural gas) as a feedstock for electricity and heat generation; these fossil fuels have not seen the same degree of price volatility as oil and furthermore, electricity markets in various EU member states are more stable than the global oil market. Thus, the impact of current economic conditions in Canada on the wood pellet market may prove to be favourable.

\section{Conclusions}

Renewable energy policies in Europe have created an opportunity in Canada for pellet production and overseas export. British Columbia has shifted exports to Asia due to increased demand, opening up the market for southeastern Canada to take advantage of Europe's rising demand for wood pellets. This study has identified a sufficient quantity of sawmill residues in the Bancroft area to support a 100000 tonne/year mill capable of producing pellets that comply with European standards. An analysis of wood currently designated as pulpwood reveals a potential high-quality biomass resource in the area. While this residue supply may become available if the pulp market collapses, a pellet mill would need to secure a contract with forest managers to access the residue. Analyzing

\footnotetext{
${ }_{7}$ http://www.nrcan.gc.ca/energy/fuel-prices/crude/4927
} 
the properties for each species and residue type demonstrated that bark could be blended with wood residue to form good quality pellets that utilize the full biomass potential of wood residues.

While the suitability of wood supply and quality in southeastern Ontario have been acknowledged, further consideration is required to optimize the economics of a pellet mill operation. Competition for raw materials from other markets or pellet mills could raise the cost and limit availability of residues. However, a steady market for residues could be economically beneficial to a sawmilling industry, which highlights the importance for the pellet mill to secure an agreement with surrounding sawmills. In addition, since transportation costs impact the production costs of wood pellets, the mill should be located in an area that minimizes transportation distance for residues. One suggestion is to locate the mill close to the largest sawmill with a secured residue stream to minimize transportation cost for the raw materials.

Europe's consumption of wood pellets continues to rise above their capacity to manufacture pellets domestically, creating an opportunity for southeastern Ontario to initiate a pellet industry. The region is well-positioned to be successful in this industry given their established forestry sector, skilled workforce, and availability and quality of wood residues.

\section{Acknowledgements}

The authors thank Loni Pierce and Kaho Hayashi for their assistance. Financial assistance from the ecoEnergy Innovation Initiative, Natural Resources Canada, is gratefully acknowledged.

\section{References}

Aguilar, F.X., B. Glavonjic, R. Hartkamp, W. Mabee and K.E. Skog. 2014. Wood energy. In UNECE/FAO Forest Products Annual Market Review, 2013-2014. Geneva, Switzerland. pp. 87-97.

Aman, A., S. Baker and W. Greene. 2011. Productivity and product quality measures for chippers and grinders on operational southern US timber harvests. Forest Products Society. Intern. J. Forest Eng. 2(2): 7-14. doi: 10.1080/14942119.2011.10702605

Arsenault, J. 2015. Canadian Pellet Industry Update. Wood Pellet Association of Canada. Available from http://www.pellet.org/ images/pellet/PFI-AGM.pdf

Bank of Canada. 2015a. Business Outlook Survey. Vol. 11.4. Available from: http://www.bankofcanada.ca/wp-content/uploads/2015/ 01/bos_winter2014.pdf [accessed 2 February 2015].

Bank of Canada. 2015b. Business Outlook Survery. Vol, 12.1. Available from: http://www.bankofcanada.ca/wp-content/uploads/2015/ 04/bos-spring2015.pdf [accessed 12 August 2015].

Canadian Biomass. 2015. 2014 Canadian Biomass Pellet Map. Available from: http://www.canadianbiomassmagazine.ca/images/ CBM-pellet-map-2014.pdf [accessed 13 January 2015].

Clarke, S. and F. Preto. 2011. Biomass Burn Characteristics Factsheet. Ministry of Agriculture, Food and Rural Affairs. Available from: http://www.omafra.gov.on.ca/english/engineer/facts/11-033 .htm\#5 [accessed July 30, 2015].

Cutshall, J., S. Baker and W. Greene. 2012. Improving woody biomass feedstock logistics by reducing ash and moisture content. $35^{\text {th }}$ Council on Forest Engineering Annual Meeting. New Bern, North Carolina [online]. Available from: http://web1.cnre.vt.edu/forestry/ cofe/documents/2012/1460_Cutshall_J-COFE2012.pdf [accessed 26 February 2015].
European Commission. 2009. Directive 2009/28/EC of the European Parliament and of the Council of 23 April on the promotion of the use of energy from renewable sources and amending and subsequently repealing Directives 2001/77/EC and 2003/30/EC. Available at http://eur-lex.europa.eu/legal-content/EN/ALL/?uri=CELEX\% 3A32009L0028 [accessed June 2015].

[EPC] European Pellet Council. 2013. Handbook for the Certification of Wood Pellets for Heating Purposes. Version 2.0 [online]. Renewable Energy House. Brussels, Belgium. Available from: http://www.enplus-pellets.eu/wp-content/uploads/2012/01/ENplusHandbook-2.0.pdf [accessed 2 March 2015].

Filbakk, T., R. Jirjis, J.Nurmi and O. Hoibo. 2011. The effect of bark content on quality parameters of Scots pine (Pinus sylvestris L.) pellets. Biomass and Bioenergy 35(8): 3342-3349. doi: 1016/j.biombioe.2010.09.011.

Flach, B., K. Bendz and S. Liberz. 2014. EU Biofuels Annual 2014 [online]. Available from: http://gain.fas.usda.gov/Recent\%20GAIN \%20Publications/Biofuels\%20Annual_The\%20Hague_EU-28_7-32014.pdf [accessed 22 January 2015].

Hagberg, L., E. Särnholm, J. Gode, T. Ekvall and T. Rydberg. 2009. LCA calculations on Swedish wood pellet production chains according to the Renewable Energy Directive. IVL Swedish Environmental Research Institute Ltd.

Hoque, M. et al. 2006. Economics of Pellet Production for Export Market. The Canadian Society for Bioengineering. Paper No. CSBE 06-103.

JWEE. 2015. The Joint Wood Energy Enquiry 2013. United Nations Economic Commission for Europe/Food and Agriculture Organization of the United Nations, Geneva, Switzerland. Available at http://www.unece.org/mc/forests/jwee.html [accessed June 2015].

Krigstin, S., K. Hayashi, J. Tchorzewski and S. Wetzel. 2012. Current inventory and modelling of sawmill residues in Eastern Canada. Forest. Chron. 88(5): 626-635.

Levin, R., S. Krigstin and S. Wetzel. 2011. Biomass availability in eastern Ontario for bioenergy and wood pellet initiatives. Forest. Chron. 87(1): 33-41.

Mani, S., S. Sokhansanj, X. Bi and A. Turhollow. 2006. Economics of Producing Fuel Pellets from Biomass. Appl. Eng. Agric. 22(3): 421-426. Doi: 10.13031/2013.20447.

[NRCan] Natural Resources Canada. 2013. Selective Cuttings: Wood pellet production trends in Canada [online]. Available from: http://cfs.nrcan.gc.ca/selective-cuttings/57 [accessed 28 January 2015].

[NREL] National Renewable Energy Laboratory. 2013. Energy Analysis: International Trade of Wood Pellets [online]. NREL Report No. BR-6A20-56791. Available from: http://www.nrel.gov/ docs/fy13osti/56791.pdf [accessed 21 January 2015].

[OMNR] Ontario Ministry of Natural Resources. 2004. Provincial Wood Supply Strategy [online]. Queen's Printer for Ontario, Toronto. Available from: https://www.ontario.ca/environment-andenergy/provincial-wood-supply-strategy [accessed 15 January 2015].

[OMNR] Ontario Ministry of Natural Resources. 2012. State of Ontario's Forests [online]. Queen's Printer for Ontario, Toronto. Available from: https://www.ontario.ca/environment-and-energy/ state-ontarios-forests-report [accessed 14 January 2015].

[OMNR] Ontario Ministry of Natural Resources. 2015. Ontario Crown Timber Charges (Stumpage) [online]. Available from http://www.lrcsde.lrc.gov.on.ca/itrees/stumpage/pdf/stumpage_141 5_12.pdf [accessed 17 March 2015].

[OPG] Ontario Power Generation. 2014. Thermal Power [online]. Available from http://www.opg.com/generating-power/thermal/ Pages/thermal.aspx [accessed 13 August 2015].

Opeongo Forestry Service. 2009. Renewable Energy from Eastern Ontario Forests: A Renfrew Country Blueprint [online]. Renfrew, Ontario. Available from: http://www.rccfdc.org/download.php? $\mathrm{dl}=$ YToyOntzOjI6ImlkIjtzOjM6IjEwOSI7czozOiJrZXkiO2k6MTt9 [accessed 12 January 2015]. 
Pulp and Paper Canada. 2014. Eastern Canada ramping up wood pellet exports [online]. Available from: http://www.pulpandpapercanada.com/news/eastern-canada-ramping-up-wood-pelletexports/1003050088/ [accessed 15 January 2015].

Roser, D. 2013. Canadian wood pellet fibre sourcing. FPInnovations. Available from: http://www.pellet.org/images/12_Dominik_Roser_WPAC.pdf [accessed 26 Aug 2015].

Rowe, J.S. 1972. Forest Regions of Canada. Canadian Forestry Service, Department of the Environment. Publication No. 1300. Ottawa, Canada.

Sonnenberg, M. 2015. OPG rejects natural gas, biomass option for Nanticoke Generating Station. Simcoe Reformer. Available from: http://www.simcoereformer.ca/2015/07/15/opg-rejects-natural-gasbiomass-option-for-nanticoke-generating-station [accessed 13 August 2015].

Statistics Canada. 2015. Canadian International Merchandise Trade Database. Domestic exports - 440131 Wood Pellets. Accessed January 12, 2015. . Available at http://www5.statcan.gc.ca/cimt-cicm
Strauss, W. 2015. What is the Impact of the Strengthening Dollar on Utility and Producer Margins? [online]. FutureMetrics LLC. Bethel, ME, USA. Available from: http://futuremetrics.info/wp-content/ uploads/2015/01/Exchange_Rates\%20_with_Dashboard_by_Future Metrics.pdf [accessed 15 January 2015].

Wood Pellet Association of Canada. 2015. Wood pellet production. Available at http://www.pellet.org/production/2-production [accessed June 2015]

[WRI] Wood Resources International LLC. 2013. Wood pellet exports from North America to Europe have doubled in two years [online]. Available from: http://www.wri-ltd.com/pdfs/GTWMU\% 20North\%20America\%20wood\%20pellet\%20exports\%202013.pdf [accessed 2 February 2015].

[WRI] Wood Resources International LLC. 2014. Wood pellet exports from North America to Europe plateaued during the 2Q 2014 [online]. Available from: http://www.wri-ltd.com/pdfs/ GTWMU\%20North\%20American\%exports\%20of\%20wood\%20pe llets\%20in\%20the\%202Q\%202014.pdf [accessed 2 February 2015]. 